\title{
IDENTIFIKASI KEBUTUHAN ALAT PEMADAM API RINGAN DI RSP UNIVERSITAS BRAWIJAYA MALANG
}

\author{
Yoga Pradipta \\ PT. Wijaya Karya (PERSERO), Tbk \\ JL. DI Panjaitan Kav.9, Jakarta 13340 \\ Email: jogjazz_deep@yahoo.com
}

\begin{abstract}
The hospital will have a high fire risk in case of fire because in accommodating a lot of patients. Extinguish the fire at the first event of a fire can use the fire extinguisher. The aim of this study was to evaluate the fire extinguisher installation planning. This research was an observational research with a descriptive analysis method. The primary data were collected with observation, interviewing and the secondary data were collected from PT Nindya Karya, Rumah Sakit Pendidikan Universitas Brawijaya Malang projects. The sample of study was selected using by purposive sampling. The variables in this study were building construction classification and fire risk, fire classification and fire extinguisher requirement. The data were analyzed using descriptive analysis. The results showed that Rumah Sakit Pendidikan Universitas Brawijaya Malang project's were public buildings classification with a low risk fire accident. This building's risk fire classification were $A, B$ and $C$. Each floor required 9 pieces of fire extinguisher with $\mathrm{CO}_{2}$ and dry powder types. This research was concluded that the fire extinguisher needs was accordance with Permenakertrans No. 4, 1980. It's suggested to use the terms and conditions of Permenakertrans No.4, 1980 about the installation and maintenance requirements in planning the installation fire extinguisher.
\end{abstract}

Keywords: Portable Fire Extinguisher identification, hospital building

\begin{abstract}
ABSTRAK
Rumah sakit akan memiliki risiko kebakaran tinggi bila terjadi kebakaran karena didalamnya menampung banyak pasien. Memadamkan api pada mula terjadi kebakaran bisa menggunakan alat pemadam api ringan. Tujuan dalam penelitian ini adalah mempelajari perencanaan pemasangan alat pemadam api ringan di Proyek Pembangunan Rumah Sakit Pendidikan Universitas Brawijaya Malang. Penelitian ini termasuk dalam penelitian observasional dengan analisis penelitian yang bersifat deskriptif. Data primer dikumpulkan dengan cara observasi dan wawancara serta data sekunder yang diperoleh dari PT. Nindya Karya, Proyek Pembangunan Rumah Sakit Pendidikan Universitas Brawijaya Malang. Sampel penelitian ditentukan dengan cara purposive sampling. Variabel dalam penelitian ini adalah klasifikasi bangunan gedung dan risiko kebakaran, klasifikasi kebakaran dan kebutuhan alat pemadam api ringan. Data yang diperoleh akan dianalisa secara deskriptif. Hasil dari penelitian ini menunjukkan bahwa Proyek Pembangunan Rumah Sakit Pendidikan Universitas Brawijaya Malang adalah bangunan umum dengan tingkat risiko kebakaran rendah. Bangunan ini memiliki risiko kebakaran golongan kelas A, B dan C. Setiap lantai membutuhkan 9 buah alat pemadam api ringan dengan jenis alat pemadam api ringan yang digunakan adalah $\mathrm{CO}_{2}$ dan dry powder. Jumlah kebutuhan dan jenis alat pemadam api ringan sesuai dengan Permenakertrans No. 4 Tahun 1980. Rumah sakit disarankan agar mengacu Permenakertrans No. 4 Tahun 1980 Tentang Syarat Pemasangan dan Pemeliharaan APAR.
\end{abstract}

Kata kunci: identifikasi APAR, gedung rumah sakit

\section{PENDAHULUAN}

Bangunan gedung menurut Peraturan Pemerintah Republik Indonesia No. 36 Tahun 2005 adalah wujud fisik hasil pekerjaan konstruksi yang menyatu dengan tempat kedudukannya, sebagian atau seluruhnya berada di atas atau di dalam tanah dan atau air, yang berfungsi sebagai tempat manusia melakukan kegiatannya, baik untuk hunian atau tempat tinggal, kegiatan keagamaan, kegiatan usaha, kegiatan sosial, budaya, maupun kegiatan khusus.
Pembangunan gedung harus memperhatikan nilai keselamatan terhadap segala ancaman bahaya yang terjadi antara lain yaitu bahaya kebakaran. Menurut Indrawan (2013), bahaya dari bangunan gedung bertingkat yaitu tinggi di mana akses untuk menyelamatkan diri adalah sedikit dan terbatas, maka perlu dilakukan tindakan pencegahan bahaya kebakaran yang efektif dan efisien dan terintegrasi dalam satu sistem manajemen sehingga implementasi dan pembaharuannya dapat mengikuti kebutuhan. 
Ramli (2010), dalam bukunya menyebutkan kasus kebakaran pernah terjadi di Rumah Sakit Bersalin ST Hadidjah IV, tidak ada korban jiwa dalam peristiwa tersebut dan penyebab kebakaran diduga akibat arus pendek listrik. Kasus tersebut menunjukkan bahaya kebakaran apabila kebakaran terjadi di rumah sakit mengingat terdapat banyak pasien di dalam gedung beserta kerugian yang diderita pihak rumah sakit. Hal tersebut dapat membuat panik pasien di dalam gedung. Menurut Ariyanto (2012), mengatakan kesadaran masyarakat untuk standarisasi pembangunan gedung bertingkat (tinggi) masih bisa dikatakan minim, sebab dalam keadaan di lapangan sangat jarang ditemukan dan tangga darurat yang efektif hanya satu. Hal ini dikarenakan tangga darurat 2 memiliki kapasitas untuk menolong korban hanya sedikit (sempit).

Indrawan (2013), menyebutkan dari sebuah data resmi dari United States National Fire Protection Association (US NFPA) yang diterbitkan tahun 2008 menjelaskan tentang kerugian yang diakibatkan dari bencana kebakaran ini rata-rata 350.000 kali bencana kebakaran di daerah perumahan dan perkantoran yang terjadi dalam setahun, 15.300 kali merupakan kejadian kebakaran di gedung bertingkat di seluruh Amerika serikat dengan rata-rata 60 orang meninggal, 930 luka-luka dan menelan kerugian sebesar 52 juta dollar mengikuti bencana kebakaran di gedung bertingkat.

Hepiman (2009), dalam penelitiannya di Rumah Sakit Jiwa di mana jika terjadi kebakaran akan menjadi bahaya yang tinggi karena mengingat pasien yang ditampung adalah orang dengan perhatian khusus. Hasil penelitian tersebut menyimpulkan bahwa jumlah APAR dan pemasangannya belum sesuai dengan ketentuan Peraturan Menteri Tenaga Kerja dan Transmigrasi No. 4 Tahun 1980. Hal yang sama juga disebutkan dalam penelitian Sanjaya (2015), di Rumah Sakit PKU Muhammadiyah Yogyakarta Unit II. Penelitian tersebut menunjukkan pemasangan dan kebutuhan APAR tidak diperhatikan secara khusus.

Berdasarkan uraian diatas perlu dilakukan sebuah usaha yang bertujuan untuk meminimalisir kerugian yang harus ditanggung akibat bahaya kebakaran. Pemasangan dan kebutuhan APAR perlu diperhatikan kesesuaiannya dengan Peraturan Menteri Tenaga Kerja dan Transmigrasi No.4 Tahun 1980 Tentang Syarat Pemasangan dan Pemeliharaan Alat Pemadam Api Ringan.

Proyek Pembangunan Gedung Rumah Sakit Pendidikan Universitas Brawijaya, Malang masih dalam proses pembangunan. Gedung $\mathrm{C}$ terdiri dari 8 lantai di mana lantai 1 hingga 4 sudah mulai digunakan sedangkan lantai 5 hingga 8 masih dalam proses pembangunan. Perencanaan pemasangan APAR perlu dilakukan mengingat lantai 5 hingga 8 masih dalam proses pembangunan sehingga dalam pengadaan APAR sesuai dengan peruntukannya.

Tujuan penelitian ini adalah mengidentifikasi kebutuhan APAR di Gedung Rumah Sakit Pendidikan Universitas Brawijaya Malang.

\section{METODE}

Berdasarkan jenis penelitian termasuk dalam penelitian observasional dengan analisis penelitian bersifat deskriptif. Data yang digunakan merupakan data yang bersumber dari hasil observasi, wawancara dan data sekunder perusahaan. Observasi digunakan pada waktu melihat kondisi gedung untuk melihat potensi bahaya kebakaran. Wawancara dilakukan kepada karyawan yang terkait dengan perencanaan sarana proteksi kebakaran di gedung Rumah Sakit Universitas Brawijaya Malang. Sampel diambil dalam penelitian ini adalah tenaga kerja di PT. Nindya Karya yang mewakili keseluruhan populasi dengan menggunakan purposive sampling dan memenuhi kriteria. Besar sampel dalam penelitian ini yaitu 4 orang yang merupakan karyawan yang mewakili dalam perencanaan sarana proteksi kebakaran di gedung Rumah Sakit Universitas Brawijaya Malang.

\section{HASIL}

Proyek pembangunan Rumah Sakit Pendidikan Universitas Brawijaya di Malang merupakan salah satu proyek yang di bangun oleh PT Nindya Karya. Proyek pembangunan rumah sakit ini dimulai pada tahun 2012 dan direncanakan akan selesai pada tahun 2017. Proyek pembangunan Rumah Sakit Pendidikan Universitas Brawijaya ini didirikan di atas tanah seluas $18.597 \mathrm{~m} 2$ yang terletak di jalan Ir. Soekarno. Proyek pembangunan gedung Rumah Sakit Pendidikan Universitas Brawijaya mempunyai luas bangunan $10.440 \mathrm{~m}^{2}$ yang terdiri dari 3 gedung yang saling terhubung satu sama lain di mana setiap gedung terdiri dari 8 lantai. Pembangunan gedung ini sudah mencapai tahap VI di mana kegiatan yang dilakukan pada tahap VI ini yaitu kegiatan arsitektur berupa peletakan batu bata, plester, acian tembok dan pemasangan batu granit pada tembok. Kegiatan lain yang dilakukan adalah mechanical electrical yang 
pekerjaannya mencakup pemasangan kelistrikan dan instalasi perpipaan.

Proyek pembangunan Rumah Sakit Pendidikan Universitas Brawijaya, Malang pada gedung C sebagian lantai sudah selesai dibangun. Bagian lantai 1 dan 2 bahkan sudah digunakan sebagai klinik kesehatan Universitas Brawijaya. Pada lantai 3 sudah selesai pengerjaannya namun belum digunakan dan pada setiap ruangannya masih kosong. Pada lantai 4 hingga 7 masih dalam tahap pekerjaan dan hampir selesai. Sedangkan pada lantai 8 sudah selesai pengerjaannya dan siap digunakan, kondisi gedung belum dipakai untuk kegiatan. Gedung C pada Proyek pembangunan Rumah Sakit Pendidikan Universitas Brawijaya ini diperuntukkan sebagai ruangan rawat inap yaitu lantai 3 hingga 7 , sedangkan pada lantai 8 akan difungsikan sebagai kantor rumah sakit.

\section{Potensi Bahaya Kebakaran}

Risiko kebakaran gedung Rumah Sakit Pendidikan Universitas Brawijaya Malang belum dapat dipastikan karena gedung ini masih dalam proses pembangunan seperti hasil wawancara berikut:

\section{“...untuk kebakaran apa yang mungkin terjadi belum bisa di pastikan, kan gedung ini belum ada isinya, jadi kita belum tahu potensi kebakarannya apa saja, yang jelas tidak akan ada kompor di setiap lantainya untuk ruang VVIP sekalipun..."(FKA- pelaksana K3).}

Berdasarkan hasil pengamatan di lantai 5 hingga 8 proyek pembangunan gedung Rumah Sakit Pendidikan Universitas Brawijaya Malang penyebab kebakaran jika dilihat dari sumber kebakaran disebabkan karena ada bahan yang bersifat mudah terbakar, dan ada pemicu untuk terjadinya kebakaran dari instalasi listrik. Identifikasi bahaya kebakaran di lantai 5 hingga 8 , meliputi:

\section{Kertas}

Kertas merupakan bahan yang mudah terbakar. Kertas pada proyek pembangunan gedung Rumah Sakit Pendidikan Universitas Brawijaya Malang berupa dokumen yang berada di ruang perkantoran, ruang staf, ruang kepala, nurse station maupun di ruang konsultasi. Kertas bisa berisiko menjadi bahan bakar apabila ada sumber panas. Sumber panas di setiap lantai bisa dihasilkan dari konsleting listrik yang dapat menimbulkan percikan api yang bersumber dari instalasi listrik maupun peralatan elektronik.

\section{Bahan Kimia}

Bahan kimia yang dimaksud dapat berupa obat yang berada di ruang tindakan atau bahan pembersih ruangan yang disimpan di dalam gudang. Bahan kimia yang tersimpan bisa menjadi bahan yang mudah terbakar apabila terdapat sumber panas atau terjadi reaksi antar bahan kimia tersebut. Risiko ini khususnya berada di lantai 5 hingga 7 .

\section{Kain}

Sumber kebakaran dapat diperkirakan berasal dari kain di setiap ruangan. Kain dalam hal ini yang dimaksud dapat berupa gorden, kain penutup tempat tidur, pakaian dan taplak meja.

\section{Peralatan Elektronik}

Peralatan elektronik digunakan di seluruh ruangan yang ada di lantai 5 hingga 8 . Peralatan elektronik yang dimaksud berupa alat kesehatan, TV, air conditioner, kipas angin dan lampu penerangan.

\section{Instalasi Listrik}

Instalasi listrik yang digunakan di proyek pembangunan Gedung Rumah Sakit Pendidikan Universitas Brawijaya Malang digunakan sebagai sumber tenaga listrik untuk menjalankan peralatan elektronik yang terdapat di setiap lantai. Instalasi listrik merupakan sumber panas yang dapat memicu terjadinya kebakaran. Bahaya dari instalasi listrik adalah terjadi korsleting sehingga timbul percikan api sehingga berpotensi terjadinya kebakaran.

\section{Klasifikasi Kebakaran}

Berdasarkan hasil wawancara yang didapatkan hasil:

“...pada intinya gedung ini punya risiko yang sama, yang pasti risiko dari kelistrikan, lalu mungkin dari putung rokok, walaupun sudah ada larangan, pasti tetap ada pengunjung yang merokok dan dibuang sembarangan,..."(FRA-pelaksana K3)

Berdasarkan dari observasi di atas, potensi kebakaran yang terdapat di Proyek pembangunan Gedung Rumah Sakit Pendidikan Universitas 
Brawijaya Malang Gedung C pada lantai 5-8 mempunyai bahaya potensi kebakaran berupa tegangan listrik yang berupa hubungan arus pendek yang dapat menyebabkan timbulnya api dan bahaya kebakaran berupa kertas yang berasal dari area perkantoran karena kertas merupakan bahan yang mudah terbakar. Ruang rawat inap mempunyai bahan mudah terbakar berupa kain dan kertas.

\section{Kebutuhan APAR}

Berdasarkan hasil dari wawancara dan data sekunder tentang jumlah dan jenis APAR yang direncanakan di PT. Nindya Karya Proyek pembangunan Gedung Rumah Sakit Pendidikan Universitas Brawijaya Malang, didapatkan hasil sebagai berikut:

\section{“...untuk jumlah APAR yang mau dipasang nanti setiap lantainya diberi 10 APAR, nah kalo masalah jenisnya apa saja nanti ditanyakan langsung saja pada subkon yang handle masalah APAR, soalnya untuk pengadaan ini yang tau subkontraktornya..." (FKA-pelaksana K3) \\ “...rencananya akan dipasang 10 APAR setiap lantainya, APAR yang digunakan hanya dua jenis yaitu powder dan $\mathrm{CO}_{2}$, pembagiannya jenisnya $\mathrm{CO}_{2} 4$ buah terus powdernya 6 buah dengan berat 4,5 $\mathrm{kg}$ kalau tidak salah, nanti bisa dilihat filenya..." (A-subkontraktor)}

Perencanaan sarana proteksi kebakaran di pembangunan Gedung Rumah Sakit Pendidikan Universitas Brawijaya Malang seluruhnya dilakukan oleh pihak subkontraktor dalam pengadaan sarana proteksi kebakaran. PT. Nindya Karya dalam perencanaan ini hanya membuat denah pemetaan

Tabel 1. Perencanaan Lokasi dan Jenis APAR di Gedung Rumah Sakit Pendidikan Universitas Brawijaya Malang

\begin{tabular}{lcc}
\hline \multirow{2}{*}{ Lokasi } & \multicolumn{2}{c}{ Jenis APAR } \\
\cline { 2 - 3 } & $\mathbf{C O}_{\mathbf{2}}$ & Dry Powder \\
\hline Lantai 5 & 4 & 6 \\
\hline Lantai 6 & 4 & 6 \\
\hline Lantai 7 & 4 & 6 \\
\hline Lantai 8 & 8 & 2 \\
\hline Jumlah & 20 & 20 \\
\hline
\end{tabular}

Sumber: data sekunder (2015)
APAR sesuai dengan potensi bahaya dan mengukur jarak pemasangan APAR di setiap lantainya. Kenyataan di lapangan dilakukan oleh pihak subkontraktor.

Data di atas didapat sesuai denah lokasi perencanaan penempatan APAR yang berada di PT. Nindya Karya Proyek pembangunan gedung Rumah Sakit Pendidikan Universitas Brawijaya Malang gedung $\mathrm{C}$ lantai 5-8. Luas lantai pada setiap lantai yang terdapat pada gedung $\mathrm{C}$ yaitu $1.579,3$ $\mathrm{m}^{2}$. Jumlah perencanaan APAR ini berdasarkan jarak dan luas lantai pada masing-masing lantai. Total jumlah perencanaan pemasangan APAR di gedung $C$ lantai 5-8 berjumlah 40 buah APAR yang terdiri dari 2 jenis APAR yang akan digunakan yaitu APAR bertekanan (pressurized) jenis $\mathrm{CO}_{2}$ dan dry powder. APAR yang akan digunakan ini berdasarkan pertimbangan jenis potensi dan klasifikasi bahaya kebakaran beserta keuntungan dan kerugian penggunaan APAR jenis tersebut. Jenis $\mathrm{CO}_{2}$ berjumlah 19 buah APAR berukuran 4,5 $\mathrm{kg}$ dan jenis dry powder berjumlah 21 buah berukuran 4,5 kg. Pada setiap lantai 5,6 dan 7 terdapat 4 APAR berjenis $\mathrm{CO}_{2}$ dan 6 APAR berjenis dry powder, sedangkan pada lantai 8 terdapat 8 APAR berjenis $\mathrm{CO}_{2}$ dan 2 APAR berjenis dry powder. Penggunaan APAR berjenis $\mathrm{CO}_{2}$ dan dry powder ini berdasarkan potensi bahaya kebakaran pada setiap lantai dan pertimbangan keuntungan dan kerugian penggunaan APAR tersebut.

Perencanaan yang dilakukan oleh PT. Nindya Karya dalam menentukan jenis APAR yang akan dipakai sesuai dengan golongan kebakaran yang merupakan risiko bahaya yang terdapat di proyek pembangunan gedung Rumah Sakit Pendidikan Universitas Brawijaya Malang.

“...pemasangan APAR memang kita yang akan melakukan, kalau masalah denah pemetaannya akan dipasang di mana saja nanti tergantung yang PT. Nindya Karya, kita menyesuaikan lagi dengan permintaan, biasanya kita mengacu pada standar peraturan dalam negeri dan luar negeri..." (A-subkontraktor)

Dry powder dan karbon dioksida merupakan APAR untuk jenis kebakaran kelas $C$, namun kedua jenis APAR tersebut juga mampu memadamkan jenis kebakaran kelas A dan B. Dasar penggunaan APAR untuk kebakaran kelas $\mathrm{C}$ adalah bahan APAR bukan merupakan konduktor listrik. 


\section{PEMBAHASAN}

Proyek pembangunan gedung Rumah Sakit Pendidikan Universitas Brawijaya Malang merupakan bangunan yang diperuntukkan untuk gedung rumah sakit. Menurut Keputusan Menteri Pekerjaan Umum No. 02 Tahun 1985 Tentang Ketentuan Pencegahan dan Penanggulangan Kebakaran pada Bangunan Gedung pasal 3 ayat 2 tentang klasifikasi bangunan, bangunan rumah sakit termasuk dalam bangunan kelas A. Bangunan kelas A, adalah bangunan yang komponen struktur utamanya harus tahan terhadap api sekurangnya 3 jam. Pengklasifikasian kelas bangunan gedung berdasarkan penggunaannya dijelaskan dalam Kepmen PU No. 26 Tahun 2008 Tentang Persyaratan Teknis Sistem Proteksi Kebakaran pada Bangunan Gedung dan Lingkungan yakni pada kelas 9a Bangunan umum, adalah bangunan gedung yang dipergunakan untuk melayani kebutuhan masyarakat umum bangunan gedung perawatan kesehatan, termasuk bagian dari bangunan gedung tersebut.

Menurut Keputusan Menteri Tenaga Kerja No. 186 Tahun 1999 Tentang Penanggulangan Kebakaran di Tempat Kerja, rumah sakit termasuk dalam hunian bahaya kebakaran ringan. Pengertian dari hunian bahaya kebakaran ringan adalah macam hunian yang mempunyai jumlah dan kemudahan terbakar rendah dan apabila terjadi kebakaran melepaskan panas rendah, sehingga menjalarnya api lambat. Gedung ini meskipun mempunyai bahaya kebakaran ringan namun tetap perlu diwaspadai ancaman bahaya kebakarannya karena rumah sakit menampung banyak penghuni didalamnya.

\section{Potensi Bahaya Kebakaran}

Berdasarkan hasil pengamatan di lantai 5 hingga 8 proyek pembangunan gedung Rumah Sakit Pendidikan Universitas Brawijaya Malang penyebab kebakaran jika dilihat dari sumber kebakaran disebabkan karena ada bahan yang bersifat mudah terbakar, dan ada pemicu untuk terjadinya kebakaran dari instalasi listrik. Identifikasi bahaya kebakaran di lantai 5 hingga 8 , meliputi:

\section{Kertas}

Kertas merupakan bahan yang mudah terbakar. Kertas pada proyek pembangunan gedung Rumah Sakit Pendidikan Universitas Brawijaya Malang berupa dokumen yang berada di ruang perkantoran, ruang staf, ruang kepala, nurse station maupun di ruang konsultasi. Menurut Ramli (2010), kertas termasuk dalam bahan bakar padat yaitu bahan yang bersifat padat. Menurut Peraturan Menteri Tenaga Kerja dan Transmigrasi No. 4 Tahun 1980 Tentang Syarat Pemasangan dan Pemeliharaan Alat Pemadam Api Ringan, kertas termasuk dalam golongan A yaitu api yang berasal dari kebakaran bahan padat kecuali logam yang apabila terbakar meninggalkan arang atau abu.

\section{Bahan kimia}

Bahan kimia yang dimaksud dapat berupa obat yang berada di ruang tindakan atau bahan pembersih ruangan yang disimpan di dalam gudang. Bahan kimia yang tersimpan bisa menjadi bahan yang mudah terbakar apabila terdapat sumber panas atau terjadi reaksi antar bahan kimia tersebut. Risiko ini khususnya berada di lantai 5 hingga 7 . Menurut Ramli (2010), bahan kimia tersebut masuk dalam kategori bahan bakar cair yaitu bahan yang bersifat cairan. Menurut Peraturan Menteri Tenaga Kerja dan Transmigrasi No. 4 Tahun 1980 bahan kimia termasuk dalam golongan B yaitu api yang berasal dari kebakaran bahan cair atau gas yang mudah terbakar.

\section{Kain}

Sumber kebakaran dapat diperkirakan berasal dari kain di setiap ruangan. Kain dalam hal ini yang dimaksud dapat berupa gorden, kain penutup tempat tidur, pakaian dan taplak meja. Kain dapat dikategorikan dalam bahan padat, apabila terbakar bahan ini akan meninggalkan bekas berupa abu, maka menurut Peraturan Menteri Tenaga Kerja dan Transmigrasi No. 4 Tahun 1980, kebakaran dari bahan bakar kain termasuk dalam klasifikasi kebakaran A.

\section{Peralatan Elektronik}

Peralatan elektronik digunakan di seluruh ruangan yang ada di lantai 5 hingga 8 . Peralatan elektronik yang dimaksud berupa alat kesehatan, TV, air conditioner, kipas angin dan lampu penerangan. Bahaya dari instalasi listrik ini, jika terjadi konsleting yang dapat menimbulkan percikan api. Pencegahan terjadinya bahaya kebakaran, wajib dilakukan pengecekan pada setiap instalasi listrik yang terdapat di area kerja. Pengecekan instalasi listrik perlu dilakukan untuk menghindari terjadinya konsleting yang dapat berpotensi terjadinya kebakaran. Menurut Peraturan Menteri Tenaga Kerja dan Transmigrasi No. 4 Tahun 1980 peralatan listrik masuk ke dalam 
golongan $\mathrm{C}$ karena dapat menyebabkan timbulnya api yang berasal dari kebakaran instalasi listrik bertegangan. Pemadaman api golongan $\mathrm{C}$ tidak boleh menggunakan APAR dengan media yang bersifat konduktor.

\section{Instalasi Listrik}

Instalasi listrik yang digunakan di proyek pembangunan gedung Rumah Sakit Pendidikan Universitas Brawijaya Malang digunakan sebagai sumber tenaga listrik untuk menjalankan peralatan elektronik yang terdapat di setiap lantai. Instalasi listrik merupakan sumber panas yang dapat memicu terjadinya kebakaran. Bahaya dari instalasi listrik adalah terjadi konsleting sehingga timbul percikan api sehingga berpotensi terjadinya kebakaran. Menurut Peraturan Menteri Tenaga Kerja dan Transmigrasi No. 4 Tahun 1980 peralatan listrik masuk ke dalam golongan $\mathrm{C}$ karena dapat menyebabkan timbulnya api yang berasal dari kebakaran instalasi listrik bertegangan. Tindakan pencegahan yang dapat dilakukan yaitu dengan selalu melakukan perawatan pada jaringan instalasi listrik dan menggunakan listrik sesuai kekuatannya, tidak membebankan pada satu jaringan saja.

Menurut Ramli (2010), nyala api terjadi karena adanya tiga unsur, yaitu "bahan bakar" (fuel), "panas" (heat) dan "oksigen" $\left(\mathrm{O}_{2}\right)$. Bahan bakar (fuel), yaitu unsur bahan bakar baik padat, cair atau gas yang dapat terbakar dan bercampur dengan oksigen dari udara.

\section{Bahan Mudah Terbakar}

Bahan mudah terbakar pada proyek pembangunan gedung Rumah Sakit Pendidikan Universitas Brawijaya Malang gedung $C$ yaitu kertas yang berbentuk dokumen yang banyak terdapat di lantai 8 karena peruntukan lantai 8 adalah sebagai area perkantoran, bahan kimia yang berupa obat dan bahan pembersih ruangan, kain di setiap ruangan yang berupa gorden, taplak meja, kain penutup tempat tidur pasien dan pakaian pasien. Kertas dan kain tergolong dalam bahan padat, sedangkan bahan kimia cair tergolong dalam bahan cair.

\section{Sumber Panas}

Sumber panas pada proyek pembangunan gedung Rumah Sakit Pendidikan Universitas Brawijaya Malang terdiri dari berbagai macam bentuk, yang pertama yaitu sumber panas mekanis seperti yang terdapat pada lift yang dikarenakan gesekan dua benda sehingga menimbulkan panas. Sumber panas yang berkaitan dengan listrik yaitu yang berasal dari instalasi listrik, contohnya bunga api listrik, listrik statis petir dan aliran listrik. Sumber panas yang berasal dari reaksi kimia misalnya bahan pembersih yang tumpah dan bereaksi dengan bahan lain.

\section{Oksigen}

Hal yang sama ditunjukkan dalam Arrazy (2013), identifikasi bahaya kebakaran terdapat beberapa kondisi, tempat dan sumber yang dapat menimbulkan kebakaran di RS Dr. Sobirin. Di antaranya api dapat bersumber dari kompor gas, tabung elpiji, genset, korsleting listrik, Repligator, bahan kimia, Autoclave, alat rontgen, alat pembakaran, tabung oksigen $\left(\mathrm{O}_{2}\right)$ ataupun juga rokok.

Menurut Ramli (2010), pembakaran tidak akan terjadi apabila kadar oksigen kurang dari $12 \%$ dari $21 \%$ oksigen di udara bebas, bahkan terdapat unsur ke empat yang mendukung terjadinya kebakaran atau disebut reaksi berantai, yaitu tanpa adanya reaksi pembakaran api tidak dapat hidup secara terus menerus. Oksigen berasal dari udara bebas dan oksigen yang berada di ruangan.

Rumah sakit memiliki berbagai ancaman bahaya kebakaran, beberapa temuan diatas merupakan sebagian potensi bahaya. Hesna (2009), menyebutkan bahwa IPAL dan incenerator memiliki risiko tinggi dalam bangunan rumah sakit.

\section{Klasifikasi Kebakaran}

Berdasarkan hasil observasi potensi kebakaran, potensi kebakaran untuk gedung $\mathrm{C}$ yaitu potensi bahaya kebakaran yang berasal dari kelistrikan yang bisa disebabkan dari hubungan arus pendek yang dapat menimbulkan percikan api. Potensi kebakaran yang kedua yaitu dokumen kertas yang berada di lantai 8 karena kertas termasuk bahan yang mudah terbakar. Potensi bahaya kebakaran yang ketiga yaitu bahan kimia. Berdasarkan identifikasi potensi kebakaran tersebut, Transmigrasi No. 4 Tahun 1980, Tentang Syarat Pemasangan dan Pemeliharaan Alat Pemadam Api Ringan (APAR) pasal 2 ayat 1, kebakaran yang ditimbulkan dari percikan api kelistrikan termasuk dalam golongan C, yaitu api yang berasal dari kebakaran instalasi listrik bertegangan. Potensi kebakaran yang timbul dari kertas sebagai bahan yang mudah terbakar termasuk dalam golongan A, yaitu api yang berasal 
dari kebakaran bahan padat kecuali logam yang apabila terbakar meninggalkan arang atau abu. Api yang ditimbulkan dari bahan kimia termasuk dalam golongan B yaitu bahan cair atau gas yang mudah terbakar.

\section{Kebutuhan APAR}

Luas lantai pada setiap lantai yang terdapat pada gedung $\mathrm{C}$ yaitu $1.579,3 \mathrm{~m}^{2}$. Jumlah perencanaan APAR ini berdasarkan jarak dan luas lantai pada setiap lantai. Total jumlah perencanaan pemasangan APAR di gedung C lantai 5-8 berjumlah 40 buah APAR yang terdiri dari 2 jenis APAR yang akan digunakan yaitu APAR bertekanan (pressurized) jenis $\mathrm{CO}_{2}$ dan dry powder. APAR yang akan digunakan ini berdasarkan pertimbangan jenis potensi dan klasifikasi bahaya kebakaran beserta keuntungan dan kerugian penggunaan APAR jenis tersebut.

\section{Kebutuhan APAR berdasarkan jumlah}

Berdasarkan Peraturan Menteri Tenaga Kerja dan Transmigrasi No.4 Tahun 1980 tentang Pemasangan dan Pemeliharaan APAR pasal 4 yang berisi bahwa setiap alat pemadam api ringan harus ditempatkan pada posisi yang mudah dilihat dengan jelas, mudah dicapai dan diambil serta dilengkapi dengan pemberian tanda pemasangan. Pemasangan dan penempatan alat pemadam api ringan harus sesuai dengan jenis dan penggolongan kebakaran. Penempatan antara alat pemadam api yang satu dengan lainnya atau kelompok satu dengan lainnya yaitu 15 meter.

Perencanaan pengadaan APAR yang dilakukan oleh PT. Nindya Karya yaitu 10 unit APAR untuk setiap lantai. APAR yang direncanakan terdiri dari dua jenis yaitu $\mathrm{CO}_{2}$ yang berjumlah 20 unit dan jenis dry powder yang berjumlah 20 unit.

Penentuan kebutuhan APAR yang dilakukan PT. Nindya Karya yaitu berdasarkan luas lantai yang harus dilindungi. Proyek pembangunan gedung Rumah Sakit Pendidikan Universitas Brawijaya Malang gedung $\mathrm{C}$ lantai 5 hingga 8 mempunyai luas ruangan yang sama yaitu seluas $1579,3 \mathrm{~m}^{2}$. Penghitungan jumlah APAR berdasarkan kriteria tersebut menggunakan cara sebagai berikut:

Jumlah kebutuhan APAR $=\frac{\text { Luas Lantai }}{\text { Luas Perlindungan per APAR }}$

Luas lantai $=1579,3 \mathrm{~m}^{2}$
Luas perlindungan per APAR

$=\pi \times \mathrm{r}^{2}$

$=3,14 \times(7,5 \mathrm{~m})$

$=176,6 \mathrm{~m}^{2}$

Jumlah kebutuhan APAR

$=$ Luas lantai : Luas perlindungan per APAR

$=1579,3 \mathrm{~m}^{2}: 176,6 \mathrm{~m}^{2}$

$=8,94 \rightarrow 9$ unit

Jumlah APAR yang dibutuhkan per lantai pada Proyek pembangunan gedung Rumah Sakit Pendidikan Universitas Brawijaya Malang gedung C lantai 5 hingga 8 berdasar Peraturan Menteri Tenaga Kerja dan Transmigrasi No. 4 Tahun 1980 tentang Syarat Pemasangan dan Pemeliharaan APAR yaitu 9 unit APAR dengan jarak pemasangan APAR yang satu dengan lainnya 15 meter. Ukuran APAR dapat disesuaikan dengan kebutuhan pada setiap lantainya sesuai dengan potensi kebakaran. Total APAR yang dibutuhkan untuk lantai 5 hingga 8 berjumlah 36 unit APAR dengan jenis media pemadaman sesuai dengan potensi bahaya yang ditimbulkan.

Hafidz (2012), dalam menentukan jumlah APAR menggunakan 3 cara penghitungan yang berbeda yaitu SKBI, SNI dan NFPA. Hasil penghitungan kebutuhan APAR menunjukkan jumlah yang berbeda dalam setiap acuan yang digunakan. Jarak pemasangan APAR juga akan berbeda untuk setiap acuan yang digunakan.

Kebutuhan APAR berdasarkan National Fire Protection Association 10 (1998), tentang Alat Pemadam Api Ringan penentuan jumlah kebutuhan APAR dapat ditentukan dengan beberapa cara, salah satunya penghitungan jumlah APAR yang dibutuhkan berdasarkan klasifikasi kebakaran. Prinsip yang digunakan sama yaitu luas lantai dibagi dengan luas perlindungan APAR. Luas perlindungan APAR sesuai dengan rating dapat dilihat pada Tabel 2 .

Klasifikasi kebakaran $\mathrm{C}$ pada gedung ini menggunakan dry powder dan $\mathrm{CO}_{2}$, APAR jenis tersebut menurut NFPA 10 tergolong dalam APAR dengan kemampuan memadamkan api kelas $\mathrm{B}$, maka penentuan APAR sebagai berikut pada Tabel 3:

Jumlah kebutuhan APAR

$=$ Luas lantai : Luas perlindungan per APAR

$=1579,3 \mathrm{~m}^{2}: 278,7 \mathrm{~m}^{2}$

$=5,6 \rightarrow 6$ unit APAR 5B

Kebutuhan jumlah APAR berdasarkan NFPA 10 (1998) yaitu membutuhkan 6 unit APAR dengan rating 5B dengan penempatan jarak APAR 9,15 
Tabel 2. Luas Perlindungan APAR

\begin{tabular}{lccc}
\hline $\begin{array}{c}\text { Rating APAR } \\
\text { kelas A }\end{array}$ & $\begin{array}{c}\text { Bahaya } \\
\text { Ringan } \\
\text { (ft) }\end{array}$ & $\begin{array}{c}\text { Bahaya } \\
\text { Sedang } \\
\text { (ft) }\end{array}$ & $\begin{array}{c}\text { Bahaya } \\
\text { Tinggi } \\
\text { (ft) }\end{array}$ \\
\hline $1 \mathrm{~A}$ & 3.000 & - & - \\
$2 \mathrm{~A}$ & 6.000 & 3.000 & - \\
$3 \mathrm{~A}$ & 11.250 & 4.500 & 3.000 \\
$4 \mathrm{~A}$ & 11.250 & 6.000 & 4.500 \\
$6 \mathrm{~A}$ & 11.250 & 9.000 & 6.000 \\
$10 \mathrm{~A}$ & 11.250 & 11.250 & 9.000 \\
$20 \mathrm{~A}$ & 11.250 & 11.250 & 11.250 \\
$40 \mathrm{~A}$ & 11.250 & 11.250 & 11.250 \\
\hline
\end{tabular}

Sumber: NFPA 10 (1998)

Tabel 3. Ukuran dan Peletakan APAR untuk Bahaya Kebakaran Kelas B

\begin{tabular}{lccr}
\hline \multirow{2}{*}{ Tipe Bahaya } & $\begin{array}{c}\text { Minimum } \\
\text { Rating }\end{array}$ & \multicolumn{2}{c}{ Jarak Maksimum } \\
\cline { 3 - 4 } & 5B & 30 & meter \\
\hline Ringan & 10B & 50 & 9,15 \\
\multirow{3}{*}{ Sedang } & 10B & 30 & 15,25 \\
& 20B & 50 & 15,25 \\
Tinggi & 40B & 30 & 9,15 \\
& 80B & 50 & 15,25 \\
\hline
\end{tabular}

Sumber: NFPA 10 (1998)

meter. APAR jenis $\mathrm{CO}_{2} 5 \mathrm{~B}$ yaitu setara dengan APAR dengan berat $11,35 \mathrm{~kg}$. APAR dengan media dry powder $5 \mathrm{~B}$ setara dengan berat $4,5 \mathrm{~kg}$.

Jumlah yang direncanakan oleh PT. Nindya Karya pada Proyek pembangunan gedung Rumah Sakit Pendidikan Universitas Brawijaya Malang gedung $C$ lantai 5 hingga 8 yaitu 10 buah per lantai. Berdasarkan perhitungan menggunakan luas perlindungan per APAR menurut Peraturan Menteri Tenaga Kerja dan Transmigrasi No. 4 Tahun 1980 Tentang Pemasangan dan Pemeliharaan APAR didapatkan hasil 9 buah per lantai. Berdasarkan perencanaan yang dilakukan oleh PT. Nindya Karya

Tabel 4. Jumlah Kebutuhan APAR

\begin{tabular}{lccc}
\hline \multirow{2}{*}{ Lokasi } & \multicolumn{3}{c}{ Kebutuhan APAR (unit) } \\
\cline { 2 - 4 } & Perencanaan & $\begin{array}{c}\text { Permenakertrans } \\
\text { No. 4/1980 }\end{array}$ & NFPA \\
\hline Lantai 5 & 10 & 9 & 6 \\
Lantai 6 & 10 & 9 & 6 \\
Lantai 7 & 10 & 9 & 6 \\
Lantai 8 & 10 & 9 & 6 \\
\hline Jumlah & 40 & 36 & 24 \\
\hline
\end{tabular}

sudah memenuhi jumlah APAR yang dibutuhkan berdasarkan Peraturan Menteri Tenaga Kerja dan Transmigrasi No. 4 Tahun 1980 Tentang Syarat Pemasangan dan Pemeliharaan APAR pasal 4 bahwa penempatan APAR berdasarkan penempatan antara alat pemadam api yang satu dengan lainnya atau kelompok satu dengan lainnya yaitu 15 meter.

Kebutuhan jumlah APAR apabila dihitung berdasarkan NFPA 10, maka masih memenuhi jumlah penghitungan namun kelas APAR yang digunakan minimal menggunakan APAR kelas 5B untuk $\mathrm{CO}_{2}$ dengan isi $11,35 \mathrm{~kg}$. Penggunaan jenis dry powder dengan isi $4,5 \mathrm{~kg}$ untuk memenuhi maksimum area yang dilindungi dengan APAR. Penggunaan APAR dengan kelas 5B maka jarak APAR yang satu dengan lainnya diatur dengan jarak 9,15 meter. Penggunaan APAR dengan kelas 10B maka jarak APAR yang satu dengan lainnya diatur dengan jarak 15,25 meter

\section{Kebutuhan APAR Berdasarkan Media Pemadam}

Menurut Kurniawan (2014), pelaksanaan pemeriksaan dan pemeliharaan sarana proteksi kebakaran jika sudah dilakukan dengan rutin, ketersediaan alat pemadam kebakaran cukup berpengaruh pada keamanan staf.

Risiko kebakaran yang dimiliki proyek pembangunan gedung Rumah Sakit Pendidikan Universitas Brawijaya Malang yaitu kebakaran yang ditimbulkan dari percikan api kelistrikan termasuk dalam golongan $\mathrm{C}$, yaitu api yang berasal dari kebakaran instalasi listrik bertegangan. Potensi kebakaran yang timbul dari kertas sebagai bahan yang mudah terbakar termasuk dalam golongan A, yaitu api yang berasal dari kebakaran bahan padat kecuali logam yang apabila terbakar meninggalkan arang atau abu. Api yang ditimbulkan dari bahan kimia termasuk dalam golongan B yaitu bahan cair atau gas yang mudah terbakar. Jenis kebakaran yang terdapat pada proyek pembangunan gedung Rumah Sakit Pendidikan Universitas Brawijaya Malang yaitu kebakaran kelas A, B dan C, sehingga kebutuhan APAR yang akan digunakan harus mencakup ketiga klasifikasi tersebut. Penggunaan APAR yang sama juga terdapat dalam penelitian Firdani (2014), untuk kelas kebakaran A, B dan C menggunakan jenis gas dan tepung.

Menurut Peraturan Menteri Tenaga Kerja dan Transmigrasi No. 4 Tahun 1980, golongan kebakaran A khususnya kertas dapat menggunakan alat 
pemadam api ringan berbahan air dan tepung kering. Golongan B dapat menggunakan alat pemadam berbahan karbon dioksida, tepung kering dan gas halon. Kebakaran golongan $\mathrm{C}$ dapat menggunakan pemadam berbahan karbon dioksida, tepung kering dan gas halon.

Peraturan Menteri Tenaga Kerja dan Transmigrasi No. 4 Tahun 1980 Tentang Pemasangan dan Pemeliharaan APAR masih menyarankan penggunaan Halon, namun sekarang halon sudah tidak dipergunakan karena mengandung senyawa Chloro Fluoro Carbon (CFC) yang dianggap merusak lapisan ozon di atmosfer sesuai dengan KEPPRES No. 23 Tahun 1992 Tentang Pengesahan "Vienna Convention for the Protection of the Ozone Layer" yang mengatur pengurangan secara bertahap dan penghentian pemakaian bahan yang merusak lapisan ozon.

Perencanaan yang dilakukan oleh PT. Nindya Karya dalam menentukan jenis APAR yang akan dipakai di proyek pembangunan Gedung Rumah Sakit Pendidikan Universitas Brawijaya Malang yaitu:

\section{Dry Powder}

Penggunaan APAR berjenis dry powder menurut Ramli (2010), memiliki beberapa keunggulan yaitu: dalam temperatur normal, tepung kering sangat stabil dan tidak mudah berubah bentuk. Unsur yang terdapat pada tepung kering tidak mengandung sifat toksik yang relatif tinggi karena itu aman digunakan. Sifat atau mekanisme pemadaman yang digunakan yaitu prinsip pemisahan (smoothering), pendinginan dan pemutusan rantai reaksi penyalaan.

Tepung kering juga memiliki kekurangan yaitu apabila tepung kering digunakan untuk pemadaman api golongan A, maka akan meninggalkan bekas berupa kerak pada permukaan benda yang terbakar.

\section{Karbon Dioksida $\left(\mathrm{CO}_{2}\right)$}

APAR berbahan karbon dioksida menurut Ramli (2010), sudah sejak lama digunakan untuk memadamkan kebakaran, khususnya untuk kebakaran gas dan peralatan listrik. Prinsip kerja karbon dioksida adalah dengan efek penyelimutan (smoothering) dan pendinginan (cooling) karena terjadinya perubahan fase dari bentuk cair menjadi gas. Media pemadam kebakaran karbon dioksida memiliki keunggulan antara lain: bersih, tidak meninggalkan bekas pada benda yang terbakar. Karbon dioksida cocok digunakan untuk peralatan seperti mesin dan alat elektronik. Murah dan mudah didapat di pasaran karena banyak digunakan. Karbon dioksida dalam konsentrasi rendah tidak beracun sehingga aman digunakan di ruangan tertutup. Karbon dioksida memiliki tekanan yang cukup untuk menyemprotkan tanpa bantuan atau tekanan dari luar, sehingga mudah digunakan.

Kelemahan dari media pemadam karbon dioksida adalah wadahnya yang berat karena harus menahan tekanan yang relatif tinggi. Karbon dioksida juga kurang efektif bila digunakan di ruang terbuka karena sifatnya yang mudah menguap. Kelemahan lainnya adalah sifat beracun dari karbon dioksida jika terhirup atau terpapar dalam konsentrasi yang tinggi akan mengakibatkan kehilangan kesadaran bahkan kematian. Orang yang memadamkan kebakaran dengan karbon dioksida dapat mengalami lemas karena kekurangan oksigen.

\section{SIMPULAN}

Berdasarkan hasil pengamatan di lantai 5 hingga 8 proyek pembangunan gedung Rumah Sakit Pendidikan Universitas Brawijaya Malang penyebab kebakaran jika dilihat dari sumber kebakaran disebabkan karena ada bahan yang bersifat mudah terbakar, dan ada pemicu untuk terjadinya kebakaran dari instalasi listrik. Identifikasi potensi bahaya kebakaran di lantai 5 hingga 8, meliputi kertas, bahan kimia, kain, peralatan elektronik dan instalasi listrik.

Proyek pembangunan gedung Rumah Sakit Pendidikan Universitas Brawijaya Malang gedung C lantai 5 hingga 8, di dalamnya memiliki jenis kebakaran kelas A, B dan C. Jenis APAR yang direncanakan di PT. Nindya Karya Proyek pembangunan gedung Rumah Sakit Pendidikan Universitas Brawijaya Malang Gedung C lantai 5 hingga 8 terdiri dari 10 buah APAR setiap lantainya. Jumlah APAR yang direncanakan dapat memenuhi persyaratan.

Pengukuran jarak penempatan APAR untuk perencanaan selanjutnya disesuaikan dengan Peraturan Menteri Tenaga Kerja dan Transmigrasi No. 4 Tahun 1980 Tentang Pemasangan dan Pemeliharaan APAR berdasarkan jarak antar APAR yaitu 15 meter. 


\section{DAFTAR PUSTAKA}

Arrazy, S. Rahmiwati. 2014. Penerapan Sistem Manajemen Keselamatan Kebakaran di Rumah Sakit Dr. Sobirin Kabupaten Musi Rawas Tahun 2013. Jurnal Ilmu Kesehatan Masyarakat UNSRI, Vol. 5, No. 2, Juli 2014:103-111.

Ariyanto. 2012. Sistem Jalur Evakuasi Tanggap Darurat Kebakaran di Gd. Graha Sainta Lt. 3 FMIPA UB Berdasarkan Campus Watching. Jurnal Fakultas Teknik. Erudio, Vol. 1, No. 1, Desember 2012: 44-49.

Firdani, E., Kurniawan. 2014. Analisis Penerapan Alat Pemadam Api Ringan (APAR) Di PT. X Pekalongan. Jurnal Kesehatan Masyarakat (e-Journal), Vol. 2, No. 5, Mei 2014: 300-308.

Hafidz, H., Sitompul. 2012. Studi Sistem Pencegahan dan Penanggulangan Kebakaran pada Pabrik Pembuatan Pesawat Terbang. Jurnal Teknik Sipil ITS, Vol. 11, No. 2, April 2012: 135-147.

Hepiman. 2009. Rancangan dan Tanggap Darurat terhadap Bahaya Kebakaran di Rumah Sakit Dr. Ernaldi Bahar Palembang Tahun 2009. Skripsi. Universitas Sriwijaya. Palembang.

Hesna, H., Suwanda. 2009. Evaluasi Penerapan Sistem Keselamatan Kebakaran pada Bangunan Gedung Rumah Sakit Dr. M. Djamil Padang. Jurnal Rekayasa Sipil Universitas Andalas, Vol. 5, No. 2, Oktober 2009: 65-76.

Indrawan. 2013. Sistem Manajemen Pencegahan Kebakaran Gedung Tinggi. Asosiasi Ahli K3 Konstruksi Indonesia. Semarang.

Keputusan Menteri Tenaga Kerja No. 186 Tahun 1999 Tentang Penanggulangan Kebakaran di Tempat Kerja.

Keputusan Presiden Republik Indonesia Nomor 23 Tahun 1992 Tentang Pengesahan Vienna Convention for The Protection of The Ozone
Layer dan Montreal Protocol on Substances That Deplete The Ozone Layer as Adjusted and Amended By The Second Meeting of The Parties London, 27-29 June 1990.

Kurniawan, S., Laksito. 2014. Evaluasi Penerapan Sistem Proteksi Kebakaran pada Bangunan Rumah Sakit (Studi Kasus RS. Ortopedi Prof. Dr. R. Soeharso Surakarta). E-Jurnal Matriks Teknik Sipil, Desember 2014: 824-832.

National Fire Protection Association. 1998. Standart for Portable Fire Extinguisher, NFPA.

Peraturan Menteri Tenaga Kerja dan Transmigrasi No. 04 Tahun 1980 Tentang Pemasangan dan Pemeliharaan Alat Pemadam Api Ringan.

Peraturan Menteri Pekerjaan Umum No. 02 Tahun 1985 Tentang Ketentuan Pencegahan Dan Penanggulangan Kebakaran Pada Bangunan Gedung.

Peraturan Menteri Pekerjaan Umum No. 26 Tahun 2008 Tentang Persyaratan Teknis Sistem Proteksi Kebakaran Pada Bangunan Gedung dan Lingkungan.

Peraturan Pemerintah Republik Indonesia Nomor 36 Tahun 2005 Tentang Peraturan Pelaksanaan Undang-Undang Nomor 28 Tahun 2002 Tentang Bangunan Gedung

Pradipta. 2016. Perencanaan Pemasangan Alat Pemadam Api Ringan di Rumah Sakit Pendidikan Universitas Brawijaya Malang Gedung C. Skripsi. Surabaya. Universitas Airlangga.

Ramli. 2010. Manajemen Kebakaran. Jakarta: Dian Rakyat.

Sanjaya. 2015. Evaluasi Sarana dan Prasarana Rumah Sakit dalam Menghadapi Bencana Kebakaran (Studi Kasus di RS PKU Muhammadiyah Yogyakarta Unit II). Tesis. Yogyakarta. Universitas Muhammadiyah Yogyakarta. 